\title{
Focus: Online Education and Technology Introduction
}

\author{
VICKI S FREEMAN
}

Medical Laboratory Science (MLS) educators continue to look for new and better ways to teach students the knowledge and skills that they will need when they graduate and become employed in the laboratory field. Educators are also challenged by administration to increase the size of their classes (but with fewer resources), make their programs more cost-effective, and meet workforce needs. In recent years, to meet these demands, distance and online learning opportunities have substantially increased in MLS programs. Currently, nineteen MLS and twenty-five Clinical Laboratory Technology programs are listed as having components of online education. ${ }^{1}$

Originally, this focus series was planned to discuss distance education and technology. However, as the articles evolved, it became evident that using the narrower term of online education was more precise when coupled with the term technology. The Focus section has been divided among two Clinical Laboratory Science journal issues with the summer issue focusing specifically on technology (Using Technology in Resource Limited Countries for Competency Based Education and Training and Moving from Face-to-Face to Online Teaching) and the education supplement discussing effective online education techniques (Staying Connected: Online Education Engagement and Retention using Educational Technology Tools and Preparing Online Students for Comprehensive Examinations). A few definitions are important, as many different terms are employed when discussing these topics.

Distance learning is an educational situation where "the instructor and students are separated by time, location, or both" 2 and can be either synchronous (real-time, instructor-led event in which all participants are virtually "in class" at the same time) or asynchronous (interaction between instructors and students occurs intermittently with a time delay) using a variety of distribution methods including technology. ${ }^{2}$ Online education is also a separation of the teacher and learner, but it uses a computer network to present or distribute educational content with two-way communication via the network so that students may communicate with instructors and each other. ${ }^{3}$ As you can see, the definition of distance education is broader and inclusive of the definition of online education. Distance education does not have to use technology in order for education to be distributed. However, online education does not necessarily need to be completely "distance," but can include a combination of modalities, including on-campus sessions. Two other terms that fit into online education are blended learning and web-enhanced courses. In blended learning, instructors "combine faceto-face instruction with online learning and reduced classroom contact hours," while web-enhanced courses are face-to-face courses that make use of the web through a course management system but do not reduce classroom time. Online resources may be used, but do not replace classroom time. ${ }^{4}$

Interestingly, students not only expect, but actually demand, that some coursework be available online. As some of the articles in this series will discuss, even students attending face-to-face classes expect to be able to access online resources including downloading previously delivered classroom lectures. But, it is also important to realize that not every student wants to take their education online nor are successful at online learning. Therefore, although faculty members need to find ways to respond to student expectations and enhance the learning of the students, they need to make sure that a variety of learning strategies are available to match the learning styles and needs of their students.

"Good teachers have always used a mix of strategies, methods and media to reach their objectives-that's not new. What is new is that today's internet-based tools 


\section{FOCUS: EDUCATIONAL TECHNOLOGY}

can facilitate communication, interaction, and collaborative learning in ways that were not possible before." 5

The challenge to faculty is to keep up-to-date on the new tools that are available and find ways to use them in an appropriate and effective manner in their classes. Questions such as whether to allow students to have computers or even cell phones in the classroom have arisen. If e-tools are being used for learning purposes in place of classroom exercises, how does an instructor measure competency? Overseas, MLS programs are moving to more competency-based curricula. Face-toface contact does not ensure competency any more than online teaching. Also, what techniques can an instructor use to keep in contact with and develop a "presence" in the online classroom if the student is totally online? And, finally, as is necessary with all programs, how can programs assess and evaluate the learning outcomes?

The purpose of this focus series is to provide information on the different tools available to an instructor when delivering online education and to show how instructors are using these tools in their courses. Four articles were selected to highlight:

- the e-tools that are available and how these tools help to engage and retain online learners;
- competency-based education in resourcelimited countries and how technology, including online resources, are used to facilitate the skills development;

- how faculty adjust their teaching and their courses to effectively facilitate learning online; and

- an assessment of learning outcomes using comprehensive exam scores.

I hope that these articles encourage clinical laboratory educators to at least try some of the online tools that are available on most campuses or at least incorporate some web-based educational resources in their courses.

\section{REFERENCES}

1. Directory of NAACLS approved Online Clinical Laboratory Education Programs. http:/www.ascls.org/leadership/sa/esa .asp\#CLEP-Online. January, 2010. [Accessed March 29, 2010]

2. From An E-Learning Glossary http://www3.imperial.ac.uk/ict/ services/teachingandresearchservices/elearning/aboutelearning/e learningglossary\#d. [Accessed March 29, 2010]

3. Keegan D. Distance Education: International Perspectives. Routledge. 1988.

4. Dziuban CD, Hartman JL, and Moskal PD. Blended Learning. ECAR research bulletin. March 30, 2004, Volume 7. Accessed at www.educause.edu/ecar/ [Accessed March 29, 2010]

5. The Node Learning Technologies Network. (2001). The Node's Guide to Blended Learning: Getting the Most out of Your Classroom and the Internet.

The Focus section seeks to publish relevant and timely continuing education for clinical laboratory practitioners. Section editors, topics, and authors are selected in advance to cover current areas of interest in each discipline. Readers can obtain continuing education credit (CE) through P.A.C.E. by completing the continuing education registration form, recording answers to the examination, and mailing a photocopy of it with the appropriate fee to the address designated on the form. Suggestions for future Focus topics and authors, and manuscripts appropriate for CE credit are encouraged. Direct all inquiries to the Clin Lab Sci Editorial Office, Westminster Publishers, 315 Westminster Court, Brandon MS 39047. (601) 214-5028, (202) 315-5843 (fax).westminsterpublishers@comcast.net. 